\title{
Article \\ Simplicilones A and B Isolated from the Endophytic Fungus Simplicillium subtropicum SPC3
}

\author{
Elodie Gisèle M. Anoumedem ${ }^{1}$, Bel Youssouf G. Mountessou ${ }^{1}$, Simeon F. Kouam ${ }^{1, *}$, \\ Abolfazl Narmani ${ }^{2,3}$ and Frank Surup 2,4,*(D) \\ 1 Department of Chemistry, Higher Teacher Training College, University of Yaoundé I, \\ Yaoundé P.O. Box 47, Cameroon; gisele.elodie@yahoo.com (E.G.M.A.); mountessou@yahoo.com (B.Y.G.M.) \\ 2 Microbial Drugs Department, Helmholtz-Centre for Infection Research (HZI), Inhoffenstr. 7, \\ 38124 Braunschweig, Germany; abolfazl.narmani2@gmail.com \\ 3 Department of Plant Protection, Faculty of Agriculture, University of Tabriz, Tabriz 51666, Iran \\ 4 German Centre for Infection Research (DZIF), Partner Site Hannover-Braunschweig, \\ 38124 Braunschweig, Germany \\ * Correspondence: kfogue@yahoo.com (S.F.K.); frank.surup@helmholtz-hzi.de (F.S.)
}

Received: 12 September 2020; Accepted: 27 October 2020; Published: 29 October 2020

\begin{abstract}
Two new tetracyclic polyketides with a spirocenter, simplicilones A (1) and B (2) were isolated from the broth-culture of the endophytic fungus Simplicillium subtropicum (SPC3) in the course of our screening for new bioactive secondary metabolites. This endophytoic fungus is naturally harboured in the fresh bark of the Cameroonian medicinal plant Duguetia staudtii (Engl. and Diels) Chatrou. The planar structures of the simplicilones were elucidated by MS and 1D as well as 2D NMR spectroscopic techniques. The relative configuration was assigned by NOESY experiments in conjunction with coupling constants; subsequently, the absolute configurations were assigned by the modified Mosher's method. The compounds showed weak cytotoxic effects against the cell line KB3.1 (in vitro cytotoxicity $\left(\mathrm{IC}_{50}\right)=25 \mu \mathrm{g} / \mathrm{mL}$ for $1,29 \mu \mathrm{g} / \mathrm{mL}$ for 2 ), but were inactive against the tested Gram-positive and Gram-negative bacteria as well as fungi.
\end{abstract}

Keywords: Duguetia staudtii; Simplicillium; simplicilones A and B; endophytic fungus

\section{Introduction}

Natural products continue to be the most promising source for new chemical entities, especially in the field of antibiotics and anticancer agents. Nearly two thirds of anti-cancer agents emanated from natural products in the period 1981 to the present day [1]. However, high rediscovery rates hamper the isolation of novel secondary metabolites, which might be suited as lead structures in drug development. One solution to this problem is the use of so far under-investigated organisms [2]. Plant-associated microorganisms, particularly endophytic fungi, which live inside healthy plants without evidently causing adversary effects to the host [3], constitute a relatively untapped source of secondary metabolites due to the high diversity of species [4].

As part of our ongoing screening program for bioactive secondary metabolites, endophytic fungi from grape vide and ash trees yielded the isolation of antibacterial and cytotoxic metabolites with new chemical structures [5-7]. Expanding this study to endophytes from African medicinal plants [8,9], strain SPC3 was isolated from a fresh bark of Duguetia staudtii (Engl. and Diels) Chatrou (formerly known as Pachypodanthium staudtii Engl. and Diels). This plant of the Annonaceae family is a large-bole tree measuring up to $40 \mathrm{~m}$ in height, with a straight cylindrical diameter of ca. $70 \mathrm{~cm}$ and long narrow leaves. It is widely distributed throughout the West and Central African regions [10], ranging from Sierra Leone to Zaire and Cameroon in the dense evergreen forest [11]. In folk medicine, various parts 
of this plant are used to treat several human ailments [12,13]. Previous chemical studies reported various compounds such as lignans, alkaloids, styrens, triterpenes and flavonoids [10-14].

From the fresh apparently healthy bark of $D$. staudtii, four endophytic fungi strains were isolated, among which was a Simplicillium sp. strain. The genus Simplicillium belongs to the Ascomycota and they have a wide host range and an extensive distribution. Since some of them play an important role in biological control [15], we investigated the strain SPC3 for its secondary metabolite production. We herein report the isolation and structural elucidation of simplicilones A and B, two secondary metabolites produced by S. subtropicum isolated from the Cameroonian medicinal plant D. staudtii (Annonaceae).

\section{Results}

A large culture of the broth-culture of the plant-derived endophytic fungus SPC3, which was identified as S. subtropicum (Table S1, Figure S1), was conducted in yeast extract-malt extract-glucose (YMG) medium and a prepared crude extract was further purified by preparative HPLC, to afford two previously undescribed secondary metabolites, named simplicilones A (1) and B (2), along with a known sterol named ergosterol (Figure 1).

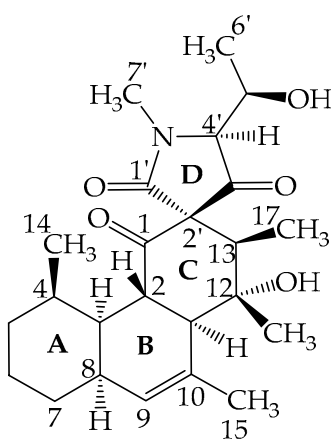

1

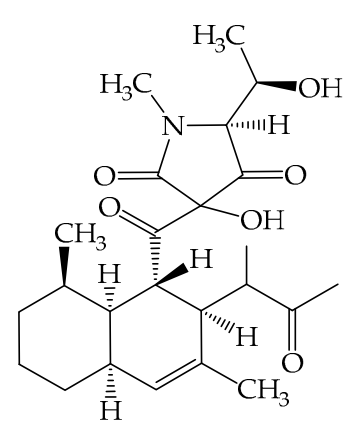

2

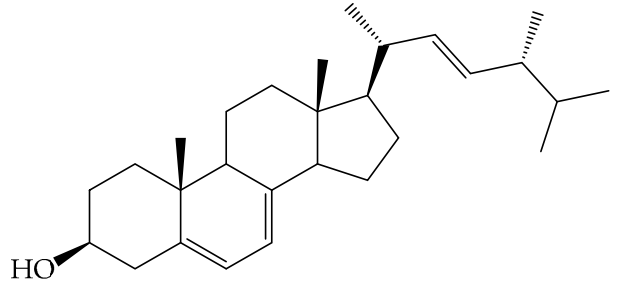

3

Figure 1. Structures of simplicilone A (1); simplicilones B (2); ergosterol (3).

\subsection{Structure Elucidation of Simplicilone A (1)}

Simplicilone A (1) was obtained as a colourless oil with the molecular formula $\mathrm{C}_{24} \mathrm{H}_{35} \mathrm{NO}_{5}$, as deduced from the (+)-high resolution electrospray mass spectrometry (HR-ESI-MS) data (Figure S2), which showed the pseudo molecular ion peak $[\mathrm{M}+\mathrm{H}]^{+}$at $\mathrm{m} / \mathrm{z} 418.2589$ (calcd. 418.2593). The ${ }^{1} \mathrm{H}$ NMR spectrum (Figure S3) showed signals of an olefinic proton $\left(\delta_{\mathrm{H}} 5.72\right)$, an oxymethine proton $\left(\delta_{\mathrm{H}} 4.04\right)$ and five methyl protons including protons of a heteroatom-linked methyl $\left(\delta_{\mathrm{H}} 3.19\right)$. Its broad band (BB) ${ }^{13} \mathrm{C}$ NMR spectrum (Figure S4) displayed signals for twenty-four carbon atoms, which were sorted by the HSQC experiment (Figure S5) into six methyl, three methylene, nine methine and six quaternary carbons including three carbonyl signals at $\delta_{C} 205.7,201.6$ and 172.7 (Table 1). The ${ }^{13} \mathrm{C}$ NMR of $\mathbf{1}$ also showed signals at $\delta_{\mathrm{C}} 132.9$ and $134.0 \mathrm{ppm}$, which were assigned to the two olefinic carbons on the fused bicyclic unit. The first fused ring system (A-B), named 4,5-disubstituted-3,7-dimethylbicyclo[4.4.0]dec-2-ene, was clearly supported by the HMBC cross peaks (see Figure S6, supplementary data) observed between the olefinic proton signals at $\delta_{\mathrm{H}} 5.72(\mathrm{H}-9)$ with the carbon signals at $\delta_{\mathrm{C}} 59.2(\mathrm{C}-11), 37.8(\mathrm{C}-3)$ and $31.4(\mathrm{C}-7)$, and also between the methyl protons at $\delta_{\mathrm{H}} 1.84(\mathrm{H}-15)$ with the carbon signals at $\delta_{\mathrm{C}} 132.9$ (C-9) and 134.0 (C-10) (Figure 2). The later HMBC correlations gave clear evidence for the attachment of the methyl group $\left(\delta_{\mathrm{H}} 1.84\right)$ at the $\mathrm{C}-10$ position of the fused ring unit (A-B). This ring was also supported by multiple COSY correlations as shown in Figure 2. In addition, the methyl group at $\delta_{\mathrm{H}} 0.72(\mathrm{H}-14)$ was located at $\mathrm{C}-4$ of the (A-B) ring, as illustrated by cross peak correlations observed between the methyl proton signals at $\delta_{\mathrm{H}} 0.72$ with the carbon signals at $\delta_{C} 39.4(C-4), 37.8(C-3)$ and $30.1(\mathrm{C}-5)$. The five-membered heterocyclic spiro ring 
unit (C-D), named 4,8,9-trisbustituted-3-methylazaspiro[4.5]deca-2,5,10-trione was deduced, and the chemical shift of $C-2^{\prime}\left(\delta_{C} 75.4\right)$ in compound 1 was comparable to that of a spiro quaternary carbon [16]. This spiro ring formed a bridge junction via $C-2\left(\delta_{C} 43.2\right)$ and $C-11(59.2)$ of the fused ring $(A-B)$ as a key ${ }^{3} J \mathrm{HMBC}$ cross peak was observed between the proton signals at $\delta_{\mathrm{H}} 2.11(\mathrm{H}-3)$ with the carbonyl carbon signal at $\delta_{C} 201.6(\mathrm{C}-1)$ and another one between the proton signals at $\delta_{\mathrm{H}} 2.11(\mathrm{H}-3)$ with the spiro quaternary carbon signal (C-2'). Further HMBC cross peaks observed between the methyl proton signals at $\delta_{\mathrm{H}} 1.37(\mathrm{H}-16)$ with the carbon signals at $\delta_{\mathrm{C}} 77.2(\mathrm{C}-12)$ and $59.2(\mathrm{C}-11)$ and also, between the methyl proton signals at $\delta_{\mathrm{H}} 0.89(\mathrm{H}-17)$ with the carbon signal at $\delta_{\mathrm{C}} 53.7(\mathrm{C}-13), \mathrm{C}-12$ and $\mathrm{C}-2^{\prime}$ clearly indicated the points of attachment of these two methyl groups (C-16 and C-17) at C-13 and C-12 positions, respectively (Figure 2). Moreover, the deshielded methyl protons at $\delta_{\mathrm{H}} 3.19\left(\mathrm{H}_{3}-7^{\prime}\right)$ resided next to the nitrogen atom as they showed HMBC cross peak correlations with the carbonyl at $\delta_{C} 172.7$ $\left(\mathrm{C}-1^{\prime}\right)$ and the carbon signal at $\delta_{\mathrm{C}} 74.3\left(\mathrm{C}-4^{\prime}\right)$. In addition, in the ${ }^{1} \mathrm{H}$ NMR spectrum, the 1-hydroxyethyl moiety was deduced from the signals at $\delta_{\mathrm{H}} 4.04(1 \mathrm{H}, \mathrm{dq}, 4.3,7.0 \mathrm{~Hz})$ and $1.34(3 \mathrm{H}, \mathrm{s})$ which was further confirmed by the ${ }^{13} \mathrm{C}$ NMR spectrum with resonances at $\delta_{C} 69.8$ and 17.6 , respectively. This moiety was attached at C- $4^{\prime}$ of the C-D ring of compound 1 as illustrated by HMBC correlations (Figure 2) observed between the methyl protons at $\delta_{\mathrm{H}} 4.04\left(\mathrm{H}-5^{\prime}\right)$ with the carbon signals at $\delta_{\mathrm{C}} 74.3\left(\mathrm{C}-4^{\prime}\right)$ and 69.8 $\left(\mathrm{C}-5^{\prime}\right)$ and also, between the methine proton at $\delta_{\mathrm{H}} 3.78\left(\mathrm{H}-4^{\prime}\right)$ with the carbon signals at $\delta_{\mathrm{C}} 205.7\left(\mathrm{C}-3^{\prime}\right)$, $75.4\left(\mathrm{C}-2^{\prime}\right), 69.8\left(\mathrm{C}-5^{\prime}\right)$ and $17.6\left(\mathrm{C}-6^{\prime}\right)$.

Table 1. ${ }^{1} \mathrm{H}(500 \mathrm{MHz})$ and ${ }^{13} \mathrm{C}(125 \mathrm{MHz})$ NMR data of compounds 1 and 2 in $\mathrm{CD}_{3} \mathrm{OD}$ and $\mathrm{CDCl}_{3}$, respectively.

\begin{tabular}{ccccc}
\hline \multirow{2}{*}{ Pos } & \multicolumn{3}{c}{$\mathbf{1}$} & $\mathbf{2}$ \\
\cline { 2 - 5 } & $\boldsymbol{\delta}_{\mathbf{C}}$ & $\boldsymbol{\delta}_{\mathbf{H}}$ (mult., $\boldsymbol{J}$ in Hz) & $\boldsymbol{\delta}_{\mathbf{C}}$ & $\boldsymbol{\delta}_{\mathbf{H}}$ (mult., $\boldsymbol{J}$ in Hz) \\
\hline 1 & 201.7 & - & 209.3 & - \\
2 & 43.2 & $3.72($ pseudo t, 11.6) & 38.8 & $4.44(\mathrm{dd}, 11.6,8.8)$ \\
3 & 37.9 & $2.11(\mathrm{dt}, 3.6,11.6)$ & 44.7 & $2.29(\mathrm{~m})$ \\
4 & 39.5 & $1.65(\mathrm{~m})$ & 38.2 & $1.70(\mathrm{~m})$ \\
5 & 30.9 & $1.29(\mathrm{~m})$ & 29.0 & $1.25(\mathrm{~m}), 1.20(\mathrm{~m})$ \\
6 & 27.8 & $1.73(\mathrm{~m}), 1.30(\mathrm{~m})$ & 28.6 & $1.76(\mathrm{~m}), 1.26(\mathrm{~m})$ \\
7 & 31.5 & $1.66(\mathrm{~m}), 1.21(\mathrm{~m})$ & 31.4 & $1.28(\mathrm{~m})$ \\
8 & 40.3 & $1.99(\mathrm{~m})$ & 39.9 & $1.98(\mathrm{~m})$ \\
9 & 134.0 & $5.72(\mathrm{br}, 6.7)$ & 131.5 & $5.73(\mathrm{brd}, 6.7)$ \\
10 & 132.9 & - & 131.9 & - \\
11 & 59.2 & $2.30(\mathrm{~d}, 11.6)$ & 46.4 & $3.22(\mathrm{dd}, 2.5,11.6)$ \\
12 & 77.3 & - & 47.4 & $2.67(\mathrm{dq}, 2.5,7.0)$ \\
13 & 53.7 & $2.51(\mathrm{q}, 7.0)$ & 211.5 & - \\
14 & 23.6 & $0.72(\mathrm{~d}, 7.3)$ & 21.4 & $0.81(\mathrm{~d}, 7.6)$ \\
15 & 25.5 & $1.84(\mathrm{~s})$ & 21.6 & $1.65(\mathrm{~s})$ \\
16 & 17.7 & $1.37(\mathrm{~s})$ & 10.1 & $1.18(\mathrm{~d}, 7.3)$ \\
17 & 11.4 & $0.88(\mathrm{~d}, 7.0)$ & 28.4 & $2.07(\mathrm{~s})$ \\
$1^{\prime}$ & 172.8 & - & 163.8 & - \\
$2^{\prime}$ & 75.5 & - & 104.9 & - \\
$3^{\prime}$ & 205.8 & - & 191.4 & - \\
$4^{\prime}$ & 74.3 & $3.78(\mathrm{~d}, 4.3)$ & 72.8 & $3.18(\mathrm{~d}, 7.6)$ \\
$5^{\prime}$ & 69.8 & $4.04(\mathrm{dq}, 4.3,7.0)$ & 65.9 & $4.13(\mathrm{dq}, 6.4,7.6)$ \\
$6^{\prime}$ & 17.6 & $1.34(\mathrm{~d}, 7.0)$ & 18.5 & $1.41(\mathrm{~d}, 6.4)$ \\
$7^{\prime}$ & 31.7 & $3.19(\mathrm{~s})$ & 45.0 & $2.97(\mathrm{~s})$ \\
\hline
\end{tabular}




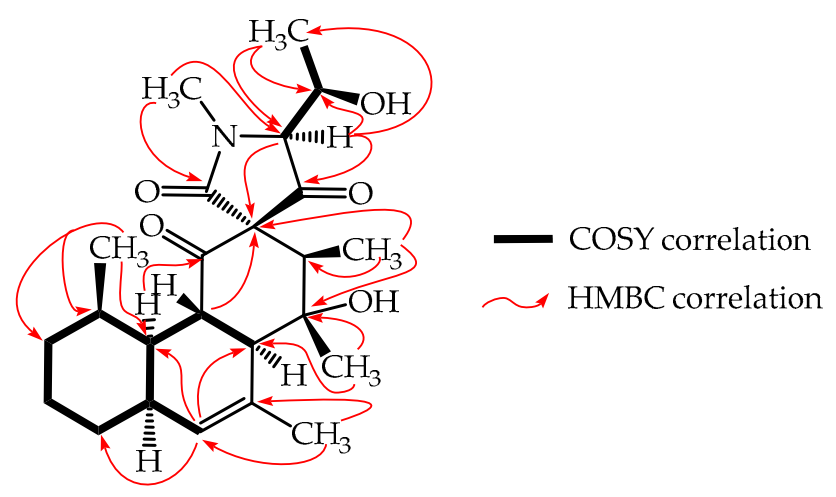

Figure 2. ${ }^{1} \mathrm{H}-{ }^{1} \mathrm{H}$ COSY and key HMBC correlations of simplicilone A (1).

Furthermore, in the rotating-frame nuclear Overhauser effect spectroscopy (ROESY) spectrum (see Figure 3 and Figure S7, supplementary data), correlations observed between the proton signals at $\delta_{\mathrm{H}} 3.72(\mathrm{H}-2)$ with those at $\delta_{\mathrm{H}} 1.37(\mathrm{H}-16)$ gave an indication of their cis-orientation, whereas in the ${ }^{1} \mathrm{H}$ NMR spectrum, the proton signals of $\mathrm{H}-2$ which concurrently coupled $(J=11.7 \mathrm{~Hz})$ with both the methine proton signals at $\delta_{\mathrm{H}} 2.30(\mathrm{H}-11)$ and $2.11(\mathrm{H}-3)$ indicated trans-orientations of $\mathrm{H}-2$ with respect to both $\mathrm{H}-3$ and $\mathrm{H}-11$. Additionally, in the ${ }^{1} \mathrm{H}$ NMR spectrum, the small value of the coupling constant $(J=3.6 \mathrm{~Hz})$ observed between $\mathrm{H}-3$ and $\mathrm{H}-8\left(\delta_{\mathrm{H}} 1.99\right)$ also indicated a cis-juncture between the $A$ and $B$ rings. These results revealed that, in the tricyclic fused ring (A-B-C), the A ring formed a chair-conformation while the $\mathrm{B}$ and $\mathrm{C}$ rings formed boat-conformations as demonstrated by Koyama et al. [17]. It is noteworthy that the methine proton $\left(\mathrm{H}-4^{\prime}\right)$ showed a cis-orientation with its vicinal homologue $\left(\mathrm{H}-5^{\prime}\right)$ as evidenced by the small value of their coupling constant $(J=4.3 \mathrm{~Hz})$, whereas in the ROESY spectrum, its correlation with the methyl protons at $\delta_{\mathrm{H}} 0.89(\mathrm{H}-17)$ gave an indication of their cis-spatial orientation.
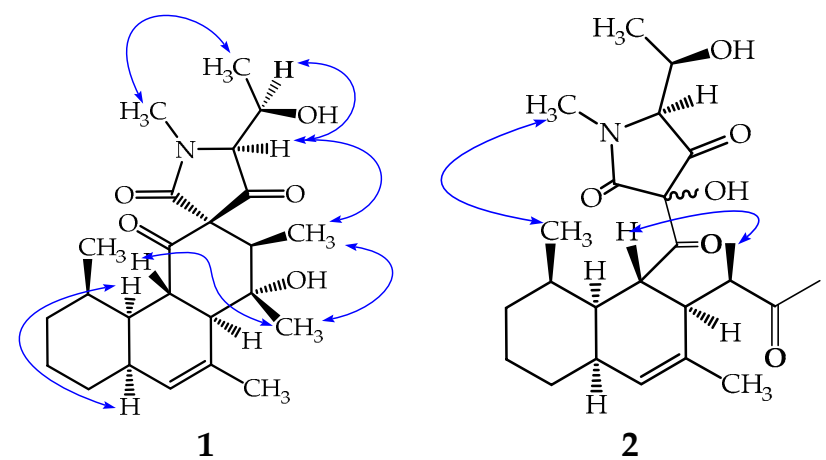

Figure 3. Key ROESY correlations of simplicilones A (1) and B (2).

The modified Mosher's method was used to determine the absolute stereochemistry at C- $5^{\prime}$ in compound 1 [18]. (R)- and (S)- $\alpha$-methoxy- $\alpha$-trifluoromethylphenylacetyl (MTPA) esters of simplicilone A (1) were prepared in pyridine- $d_{5}$ in situ by the treatment of 1 with (S)and $(R)-\alpha$-methoxy- $\alpha$-trifluoromethylphenylacetyl (MTPA) chloride, respectively. Significant $\Delta \delta$ values $\left(\Delta \delta=\delta_{\text {S-MTPA-ester }}-\delta_{\text {R-MTPA-ester }}\right)$ were observed for the protons near the chiral centre $C-5^{\prime}$ as shown in Figure 4. Thus, the absolute configuration at $C-5^{\prime}$ was determined as $(R)$. This configuration was used as a starting point and consequently, the other configurations of stereogenic centres in compound 1 were determined (Figure 3) by combination of coupling constants and significant ROESY correlations. Coupling constants of $J_{\mathrm{H} 4^{\prime}, \mathrm{H} 5^{\prime}}=4.3 \mathrm{~Hz}, J_{\mathrm{H} 4^{\prime}, \mathrm{C} 5^{\prime}}=2.5 \mathrm{~Hz}, J_{\mathrm{H} 4^{\prime}, \mathrm{C} 6^{\prime}}=1.9 \mathrm{~Hz}$ indicated a gauche conformation between $4^{\prime}-\mathrm{H}$ and $5^{\prime}-\mathrm{H}$ as well as $\mathrm{CH}_{3}-6^{\prime}$ and an anti-periplanar conformation between $4^{\prime}-\mathrm{H}$ and $5^{\prime}-\mathrm{OH}$ (Figure 5). The small coupling constants $J_{\mathrm{H} 5^{\prime}, \mathrm{C} 4^{\prime}}=2.5 \mathrm{~Hz}$ and $J_{\mathrm{H}} 5^{\prime}, \mathrm{C} 3^{\prime}$ $=2.2 \mathrm{~Hz}$ indicate an anti-peri-planar conformation of $5^{\prime}-\mathrm{H}$ and the nitrogen atom, but a gauge 
conformation between $5^{\prime}-\mathrm{H}$ and C-3'. Taken together, this information supports a $4^{\prime} S, 5^{\prime} R$ configuration. The coupling constants of $J_{\mathrm{H} 13, \mathrm{C} 1^{\prime}}=3.3 \mathrm{~Hz}$ and $J_{\mathrm{H} 13, \mathrm{C} 3^{\prime}}=7.5 \mathrm{~Hz}$, together with the observed ROESY correlation between $17-\mathrm{H}_{3}$ and $4-\mathrm{H}$, allowed to span the stereochemical information via the spiro centre to the remaining stereocenters. Thus, the structure of compound $\mathbf{1}$ was assigned to simplicilone A (Figure 1).

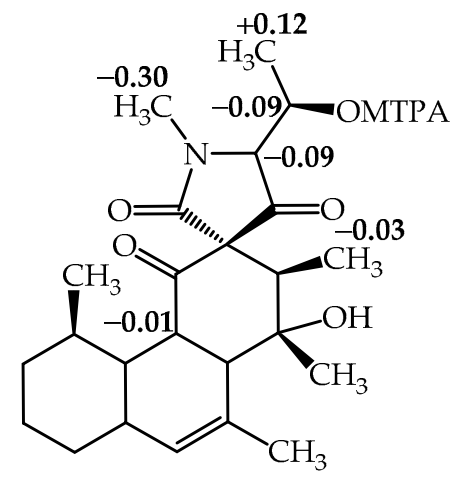

Figure 4. $\Delta \delta^{S R}$ values (ppm) for the C-5' $\alpha$-methoxy- $\alpha$-trifluoromethylphenylacetyl (MTPA) esters of compound 1.

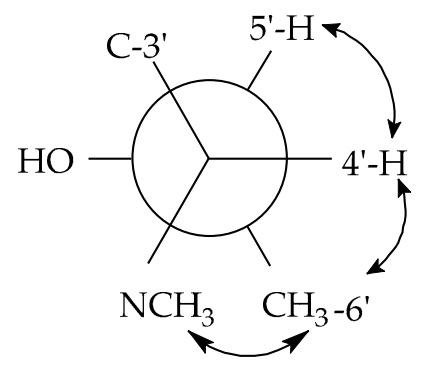

Figure 5. $J$-based analysis of $4^{\prime}-\mathrm{H} / 5^{\prime}-\mathrm{H}$ bond. Arrows indicate observed ROESY correlations.

\subsection{Structure Elucidation of Simplicilone B (2)}

Compound 2, named simplicilone B (Figure 1), was obtained as a colourless oil. Its molecular formula was determined as $\mathrm{C}_{24} \mathrm{H}_{35} \mathrm{NO}_{6}$ from the pseudo molecular ion peak $[\mathrm{M}+\mathrm{H}]^{+}$at $m / z 434.2542$ (calculated for $\mathrm{C}_{24} \mathrm{H}_{35} \mathrm{NO}_{6}$ : 434.2542), obtained by (+)-HR-ESI-MS (see Figure S8) and is consistent with eight double bond equivalents. Its ${ }^{1} \mathrm{H},{ }^{13} \mathrm{C}, \mathrm{COSY}, \mathrm{HSQC}$ and HMBC NMR spectra (see Figures S9-S13) exhibited similarities to those of compound 1. Thus, it was obvious that the structure of compound 2 could be deduced by careful comparison of its data to those of compound 1. Its molecular ion as shown by HR-ESI-MS differed by 16 amu from that of compound 1, suggesting compound 2 to have an additional oxygen atom. This information was further supported by the ${ }^{13} \mathrm{C}$ NMR spectrum which showed four carbonyl carbon signals (instead of three) at $\delta_{C} 221.5, \delta_{C} 209.3(C-1), 191.4\left(C-3^{\prime}\right)$ and $163.8\left(C-1^{\prime}\right)$. Three of them were similar to those observed in the ${ }^{13} \mathrm{C}$ NMR spectrum of compound 1 (see Table 1). Although characteristic signals due to the A-B fused ring were observed in both ${ }^{1} \mathrm{H}$ and ${ }^{13} \mathrm{C}$ NMR spectra, in the HMBC the two methyl signals at $\delta_{\mathrm{H}} 2.07$ and $\delta_{\mathrm{H}} 1.18$ showed strong cross peaks to the additional carbonyl signal at $\delta_{C} 221.5$, indicating the loss of the spiro centre found in compound 1. This was further confirmed in the HMBC spectrum where the methine proton signal of the heterocyclic ring at $\delta_{\mathrm{H}} 3.18\left(\mathrm{H}-4^{\prime}\right)$ showed a cross peak with the deshielded $\mathrm{sp}^{3}$ oxygenated carbon at $\delta_{C} 104.9$, instead of $\delta_{C} 75.4$ for the spiro quaternary carbon (C-2') observed in compound 1. In the ${ }^{1} \mathrm{H}$ NMR and HMBC spectra (Figures S9 and S12), signals for 2-keto-1-methylpropyl group were deduced from the signal of a three-proton singlet at $\delta_{\mathrm{H}} 5.76(\mathrm{H}-17)$ which showed an HMBC cross peak with the carbonyl signal at $\delta_{\mathrm{C}} 221.5$ (C-13); a methyl signal at $\delta_{\mathrm{H}} 1.18$ displayed cross peaks with the carbon signals at $\delta_{C} 46.3(C-11), 47.4(C-12)$ and C-13; a methine proton doublet of quadruplet at 
$\delta_{\mathrm{H}} 2.67(2.5,7.0 \mathrm{~Hz}, \mathrm{H}-12)$ exhibited ${ }^{3} J \mathrm{HMBC}$ cross peaks with the carbon signals at $\delta_{\mathrm{C}} 131.4(\mathrm{C}-10)$ and 28.4 (C-10). It is noteworthy that the same ROESY correlations (Figure S14) were observed for both compounds $\mathbf{1}$ and $\mathbf{2}$. This information was obviously expected, since the two compounds were isolated from the same organism. However, the stereochemistry at C-2' was not determined. Based on the above investigations, the structure of compound 2 was determined as shown in Figure 1.

\subsection{Biological Activity of Simplicilones A (1) and B (2)}

To evaluate the biological activity of the metabolites, $\mathbf{1}$ and $\mathbf{2}$ were tested against a selection of microorganisms (Table S2). However, both compounds did not show any activity against the Gram-positive bacteria Bacillus subtilis DSM10, Staphylococcus aureus DSM 346, Micrococcus luteus DSM 1790, Mycolicibacterium smegmatis ATCC 700084; the Gram-negative bacteria Chromobacterium violaceum DSM 30191, Escherichia coli DSM 1116, Pseudomonas aeruginosa PA14 nor the fungi Candida albicans DSM 1665, Schizosaccharomyces pombe DSM70572, Mucor hiemalis DSM 2656, Pichia anomala DSM 6766, Rhodotorula glutinis DSM 10134 up to $67 \mu \mathrm{g} / \mathrm{mL}$.

Assessing the cytotoxicity, $\mathbf{1}$ and $\mathbf{2}$ displayed cytotoxicity with in vitro cytotoxicity $\left(\mathrm{IC}_{50}\right)$ values of 25 and $29 \mu \mathrm{g} / \mathrm{mL}$, respectively, against the cervix carcinoma cell line KB3.1, but were inactive against the murine fibroblast cell line L929 (Table 2).

Table 2. Cytotoxic activities of $\mathbf{1}$ and $\mathbf{2}$ (in vitro cytotoxicity $\left(\mathrm{IC}_{50}\right)$ in $\mu \mathrm{g} / \mathrm{mL}$ ).

\begin{tabular}{cccc}
\hline Cell Line & $\mathbf{1}$ & $\mathbf{2}$ & Reference $\left(\mathrm{IC}_{\mathbf{5 0}}\right)$ \\
\hline L929 $\left(\mathrm{IC}_{50}\right)$ & - & - & Epothilone B $(0.00062)$ \\
KB3.1 $\left(\mathrm{IC}_{50}\right)$ & 25 & 29 & Epothilone B $(0.00003)$ \\
\hline
\end{tabular}

\section{Discussion}

The present study describes the isolation of two compounds named simplicilones A (1) and B (2), structurally related to vermisporin PF 1052 and spylidone, two compounds produced by different fungi, Ophiobolus vermisporus [19] and Phoma sp. [17,20], respectively. They are not related to secondary metabolites isolated from the genus Simplicillium so far [21-26]. Simplicilone compounds have a core-shell structure related to congeners produced by other fungi $[19,20]$. In fact, the presence of the two methyl groups in rings A and B, respectively, as compared to the related compounds described in the literature $[17,19,20]$, might suggest different biogenetic pathways for the new isolated compounds (1 and 2). This study further extends the range of compounds produced by the genus Simplicillium and then strengthens the assumption made by Koyama et al. [17] on the fact that spylidone (with a similar core structure with $\mathbf{1}$ and 2) was really a metabolite produced by a fungus. Additionally, the co-occurrence of ergosterol (3), a typical and common metabolite of fungi further confirms the fungal origin of the two isolated compounds. The HPLC analysis of the crude extract suggested the presence of several derivatives which were not isolated due to their low amount.

Regarding the biological activity, the $\mathrm{IC}_{50}$ values of the two compounds (1 and $\left.\mathbf{2}\right)$ on two cancer cell lines were evaluated and the result indicates weak cytotoxic effects of the two simplicilones on the epidermoid carcinoma cell lines KB3.1, although no effect was observed on the L929 cell line. The lower $\mathrm{IC}_{50}$ of compound $\mathbf{1}$ on the cell line KB3 as compared to that of compound $\mathbf{2}$ may presumably be due to the spiro carbon on the C-D ring, leading to an overall more rigid backbone. Furthermore, the reinvestigation of the fungus strain SPC3 still remains challenging as well as the inhibition of lipid droplet accumulation in mouse macrophages as reported by Koyama et al. [17] for spylidone.

\section{Materials and Methods}

\subsection{General Experimental Procedures}

The ${ }^{1} \mathrm{H}$ and ${ }^{13} \mathrm{C}$ NMR spectra were recorded on a Bruker Advance $500 \mathrm{MHz}$ spectrometer. Coupling constants are given in hertz $(\mathrm{Hz})$, chemical shifts in parts per million (ppm) were referenced 
to the solvent signals chloroform- $d\left({ }^{1} \mathrm{H}, \delta_{\mathrm{H}}=7.27 \mathrm{ppm} ;{ }^{13} \mathrm{C}, \delta_{\mathrm{C}}=77.00 \mathrm{ppm}\right)$ and $\mathrm{CD}_{3} \mathrm{OD}\left({ }^{1} \mathrm{H}, \delta_{\mathrm{H}}=\right.$ $\left.4.86 \mathrm{ppm} ;{ }^{13} \mathrm{C}, \delta_{\mathrm{C}}=49.15 \mathrm{ppm}\right)$. HPLC-DAD-MS analysis was performed using an amazon speed ETD ion trap mass spectrometer (Bruker Daltonics, Billerica, Massachusetts) in positive and negative ionization modes. The mass spectrometer was coupled to an Agilent 1260 series HPLC-UV system (Agilent Technologies, Santa Clara, CA, USA) (column $2.1 \times 50 \mathrm{~mm}, 1.7 \mu \mathrm{m}, \mathrm{C} 18$ Acquity uPLC BEH (Waters, Eschborn, Germany)). Solvent A was made up of: $\mathrm{H}_{2} \mathrm{O}+0.1 \%$ formic acid and solvent $\mathrm{B}$ was consisted of acetonitrile $(\mathrm{ACN})+0.1 \%$ formic acid. The stepwise gradient of solvent was: $5 \% \mathrm{~B}$ for $0.5 \mathrm{~min}$, increasing to $100 \% \mathrm{~B}$ in $20 \mathrm{~min}$, maintaining isocratic conditions at $100 \% \mathrm{~B}$ for $10 \mathrm{~min}$, flow: $0.6 \mathrm{~mL} / \mathrm{min}$, UV-vis detection 200-600 nm. HR-ESI-MS spectra were recorded on a maxis ESI TOF mass spectrometer (Bruker Daltonics, Billerica, MA, USA) (scan range m/z 100-2500, rate $2 \mathrm{~Hz}$, capillary voltage $4500 \mathrm{~V}$, dry temperature $200{ }^{\circ} \mathrm{C}$ ), coupled to an Agilent 1200 series HPLC-UV system (column $2.1 \times 50 \mathrm{~mm}, 1.7 \mu \mathrm{m}, \mathrm{C} 18$ Acquity uPLC BEH (Waters, Milford, MA, USA), solvent $\mathrm{A}: \mathrm{H}_{2} \mathrm{O}+0.1 \%$ formic acid; solvent $\mathrm{B}$ : acetonitrile $+0.1 \%$ formic acid, gradient: $5 \% \mathrm{~B}$ for $0.5 \mathrm{~min}$, increasing to $100 \% \mathrm{~B}$ in $19.5 \mathrm{~min}$, maintaining $100 \% \mathrm{~B}$ for $5 \mathrm{~min}, \mathrm{FR}=0.6 \mathrm{~mL} / \mathrm{min}$, UV-vis detection $200-600 \mathrm{~nm}$ ). The molecular formulas were calculated including the isotopic pattern (Smart Formula algorithm). Preparative HPLC purification was performed at room temperature on an Agilent 1100 series preparative HPLC system (ChemStation software (Rev. B.04.03 SP1); binary pump system; column: Kinetex 5u RP C18, dimensions $250 \times 21.20 \mathrm{~mm}$; mobile phase: acetonitrile $+0.05 \%$ trifluoroacetic acid (TFA) and water + $0.05 \% \mathrm{TFA}$; flow rate $20 \mathrm{~mL} / \mathrm{min}$; diode-array UV detector).

\subsection{Isolation of Endophytic Fungus}

The endophytic fungi were isolated from the fresh bark of the apparently healthy plant Duguetia staudtii, collected in July 2017, at the Dja rain forest in the locality of Lomié-Bertoua (GPS coordinates provided by system WGS8: Altitude 665 m; Latitude N $4^{\circ} 34^{\prime} 38^{\prime \prime}$; Longitude E $13^{\circ} 41^{\prime} 04^{\prime \prime}$ ), in the East Region of Cameroon. The botanical identification was done by Mr. Victor Nana, a botanist at the National Herbarium of Cameroon where a voucher specimen was deposited under the number 52711HNC. The general isolation procedures were carried out as previously described by Petrini [27] with slight modifications. In brief, the fresh barks $(5 \times 5 \mathrm{~cm}$ length) of $D$. staudtii were thoroughly washed with running tap water, then sterilized in $75 \%$ ethanol for $60 \mathrm{~s}$, in 3\% sodium hypochlorite $(\mathrm{NaClO})$ for $10 \mathrm{~min}$ and finally in $75 \%$ ethanol for $30 \mathrm{~s}$. These barks were then rinsed three times in sterile distilled water and dried on sterile tissue paper in the laminar flow hood. Small segments were transferred to the Potato Dextrose Agar (PDA) plate supplemented with $100 \mathrm{mg} / \mathrm{mL}$ penicillin and 100 $\mu \mathrm{g} / \mathrm{mL}$ streptomycin sulphate, then incubated at $28^{\circ} \mathrm{C}$. After a week, the purification was performed using the hyphae tip technique. This step led to the purification of four endophytic fungi on which chemical pre-screenings were carried out. Thereafter, one potential endophytic fungus (SPC3) was selected for large scale fermentation.

\subsection{Molecular Analysis, Sequencing and Phylogenetic Analysis of Endophytic Fungus}

Genomic DNA was extracted from fungal colonies growing on YMG using the EZ-10 Spin Column Genomic DNA Miniprep kit (Bio Basic Canada Inc., Markham, ON, Canada) following the manufacturer's protocol. Molecular analysis was carried out using sequence data of internal transcribed spacer (ITS) regions. Amplification was performed using an ITS1F/ITS4 primer pair [28] in a total reaction volume of $25 \mu \mathrm{L}$, which was composed of 10-15 ng genomic DNA, $1 \times$ PCR buffer, $200 \mu \mathrm{M}$ of each dNTP, $1.5 \mathrm{mM} \mathrm{MgCl} 2,0.4 \mathrm{pM}$ of each primer and $0.5 \mathrm{U}$ Taq polymerase. The reaction was performed on a Eppendorf PCR System with cycling conditions consisting of 5 min at $96^{\circ} \mathrm{C}$ for primary denaturation, followed by 35 cycles of denaturation at $94{ }^{\circ} \mathrm{C}$ for $40 \mathrm{~s}$, annealing at $52{ }^{\circ} \mathrm{C}$ for $30 \mathrm{~s}$, extension at $72{ }^{\circ} \mathrm{C}$ for $60 \mathrm{~s}$, with a final extension at $72{ }^{\circ} \mathrm{C}$ for $7 \mathrm{~min}$.

The amplicons were Sanger sequenced in both directions using BigDye v3.1. The resulting consensus sequence files were edited using SeqMan software in the Lasergene package (DNASTAR Inc., Madison, WI, USA) and consensus sequence was compared with sequences in the GenBank using 
the Basic local alignment search tool (BLAST). The ITS-rDNA sequence was deposited in GenBank with the accession number MW074157.

Reference ITS-rDNA sequence data of related/representative Simplicillium species were obtained from GenBank. Bayesian analyses were performed in PAUP v.4.0b10 and MrBayes v3.2.2 [29]. The most suitable model of evolution was estimated by using Mrmodeltest v.2.2 [30].

\subsection{Fermentation, Extraction and Isolation}

Pieces of a well-grown agar culture of S. subtropicum SPC3 were inoculated in a 500 mL-Erlenmeyer flask containing $200 \mathrm{~mL}$ of YMG medium consisting of $1.0 \%$ malt extract, $0.4 \%$ glucose, and $0.4 \%$ yeast extract, $\mathrm{pH} 6.3$ and incubated at $23^{\circ} \mathrm{C}$. After 6 days, the cultures were harvested. The supernatant was filtrated from fungal mycelia and the latter were further extracted with acetone and the combined acetone solution was concentrated under reduced pressure to yield $2 \mathrm{~g}$ of dark extract. Its purification was done by preparative HPLC using a gradient of $0-15 \%$ solvent B for $3 \mathrm{~min}, 15-100 \%$ B for $20 \mathrm{~min}$, and $1.0 \% \mathrm{~B}$ for $10 \mathrm{~min}$. The obtained fractions were combined according to concurrent HPLC-MS-UV (DAD) analyses and yielded the isolation of compounds 1 (1.4 mg; RT = $9.1 \mathrm{~min})$ and $2(1.9 \mathrm{mg}$; RT = $12.0 \mathrm{~min})$.

Simplicilones A (1): colourless oil, UV (MeOH): $\lambda_{\max }$ (PDA): $224 \mathrm{~nm} ;{ }^{1} \mathrm{H}$ NMR $\left(500 \mathrm{MHz}, \mathrm{CDCl}_{3}\right)$ and ${ }^{13} \mathrm{C}$ NMR $\left(125 \mathrm{MHz}, \mathrm{CDCl}_{3}\right)$ are shown in Table 1 ; HRMS $[\mathrm{M}+\mathrm{H}]^{+} \mathrm{m} / \mathrm{z}$ 418.2589, (calcd. for $\left.\mathrm{C}_{24} \mathrm{H}_{36} \mathrm{NO}_{5}, 418.2593\right)$.

Simplicilones B (2): colourless oil, UV (MeOH): $\lambda_{\max }$ (PDA): $225,287 \mathrm{~nm} ;{ }^{1} \mathrm{H}$ NMR $(500 \mathrm{MHz}$, $\left.\mathrm{CDCl}_{3}\right)$ and ${ }^{13} \mathrm{C} \mathrm{NMR}\left(125 \mathrm{MHz}, \mathrm{CDCl}_{3}\right)$ are shown in Table 1; HRMS [M + H] ${ }^{+} \mathrm{m} / \mathrm{z} 434.2542$ (calcd. for $\left.\mathrm{C}_{24} \mathrm{H}_{36} \mathrm{NO}_{6}, 434.2542\right)$.

\subsection{Bioassay for Cytotoxic Activity}

In vitro cytotoxicity $\left(\mathrm{IC}_{50}\right)$ of the pure compounds was investigated against the established mouse fibroblast cell line L929 (DSMZ no. ACC 2) and KB3.1 using the 3-(4,5-dimethylthiazol-2-yl)-2,5diphenyltetrazolium bromide (MTT) method in 96-well microplates for tissue cultures. The cell line L929 was cultured in Dulbecco's modified Eagle's medium (DMEM; Lonza, Basel, Switzerland), supplemented with 10\% foetal bovine serum (FBS; Thermo Fisher Scientific, Waltham, MA, USA) and incubated under $10 \% \mathrm{CO}_{2}$ at $37^{\circ} \mathrm{C}$ for 5 days. The assay was conducted following the procedure described previously [31].

\subsection{Bioassay for Anti-Microbial Activity}

Minimum inhibitory concentrations (MICs) of 1 and 2 were determined in a standard microdilution assay using Bacillus subtilis DSM10, Staphylococcus aureus DSM 346, Micrococcus luteus DSM 1790, Mycolicibacterium smegmatis ATCC 700084, Chromobacterium violaceum DSM 30191, Escherichia coli DSM 1116, Pseudomonas aeruginosa PA14, Candida albicans DSM 1665, Schizosaccharomyces pombe DSM70572, Mucor hiemalis DSM 2656, Pichia anomala DSM 6766, Rhodotorula glutinis DSM 10134 as test organisms for evaluating antibacterial and antifungal activities. The assay was carried out in 96-well microtiter plates with U-base (TPP Techno Plastic Products AG, Trasadingen, Switzerland) providing embroyid bodies (EBS) medium $(0.5 \%$ casein peptone, $0.5 \%$ glucose, $0.1 \%$ meat extract, $0.1 \%$ yeast extract, $50 \mathrm{mM}$ HEPES (11.9 g/L), pH 7.0) for bacteria and YMG medium (1.0\% malt extract, $0.4 \%$ glucose, $0.4 \%$ yeast extract, $\mathrm{pH}$ 6.3) for yeasts and filamentous fungi. First, a stock culture of each bacterium and yeast was transferred to Erlenmeyer flasks $(100 \mathrm{~mL})$ filled with $30 \mathrm{~mL}$ of the respective growth medium. Suspensions of B. subtilis and C. albicans were incubated on a rotary shaker at $30^{\circ} \mathrm{C}$ for $18-24 \mathrm{~h}$, while E. coli was grown at $37^{\circ} \mathrm{C}$. Subsequently, the cultures were adjusted to cell densities of $6.7 \times 10^{5}$ cells $/ \mathrm{mL}$ using a hemocytometer. The spore suspension of $M$. hiemalis was prepared at a concentration of $6.7 \times$ $10^{5}$ conidia/mL using YMG medium. For the test, $20 \mu \mathrm{L}$ aliquots of 1 and 2 at $1.5 \mathrm{mg} / \mathrm{mL}$ in MeOH and $20 \mu \mathrm{L}$ of the appropriate reference drug (broad spectrum antibiotic ciprofloxacin and antifungal cycloheximide at $1.5 \mathrm{mg} / \mathrm{mL}$ ) were pipetted into the first row (A) of the 96-well microtiter plate. $\mathrm{MeOH}$ 
$(20 \mu \mathrm{L})$ served as a negative control. Using a multichannel pipette, $150 \mu \mathrm{L}$ of the prepared inoculum comprising the test pathogen in the respective culture medium was aliquoted in all the rows. To the first row, an additional $130 \mu \mathrm{L}$ of the pathogen-medium mixture was added and mixed by repeated pipetting, before transferring $150 \mu \mathrm{L}$ of this mixture to the second row. A 1:1 serial dilution was conducted in the subsequent rows to generate final compound concentrations ranging from 100 to 0.78 $\mu \mathrm{g} / \mathrm{mL}$. An amount of $150 \mu \mathrm{L}$ was discarded after the last row $(\mathrm{H})$. Plates were incubated at $30{ }^{\circ} \mathrm{C}$ on a microplate vibrating shaker (Heidolph Titramax 1000, Schwabach, Germany) at $600 \mathrm{rpm}$ for 24-48 h. The lowest concentration of the compounds preventing visible growth of the test organism was recorded as the MIC [32].

\section{Conclusions}

This study describes the isolation of two new compounds named simplicilones A (1) and B (2), and their bioactivity on the two cancer cell lines: epidermoid carcinoma KB3.1 and L929. The structures of the new simplicilones were determined based on their NMR and HRESIMS data and their absolute stereochemistries were obtained based on the modified Mosher's method. Although these compounds showed weak activity on the two cancer cell lines, the inhibition of lipid droplet accumulation in mouse macrophages, as reported by Koyama et al. [17] for spylidone remains to be reinvestigated.

Supplementary Materials: The following are available online at http://www.mdpi.com/2079-6382/9/11/753/s1, Molecular phylogenetic analysis, Table S1: Results of the megablast search analysis at NCBI's GenBank nucleotide database for strain SPC3, Minimum inhibitory concentrations (MIC) of 1-2. n.i.: no inhibition up to $66.7 \mu \mathrm{g} / \mathrm{mL}$, Figure S1: Consensus phylogram (75\% majority rule) of 1002 trees resulting from a Bayesian analysis of ITS sequence alignment using MrBayes v. 3.2.2 of various Simplicilium species. The scale bar indicates 0.04 expected changes per site. The tree was rooted to Verticillium fungicola var. fungicola CBS 992.69 (EF641889.1), Figure S2: HRESI-Mass spectrum of simplicilone A (1), Figure S3: ${ }^{1} \mathrm{H}$ NMR (500 MHz, $\left.\mathrm{CDCl}_{3}\right)$ spectrum of simplicilone A (1), Figure S4: ${ }^{13} \mathrm{C}$ NMR $\left(500 \mathrm{MHz}, \mathrm{CDCl}_{3}\right)$ spectrum of simplicilone A (1), Figure S5: HSQC spectrum of simplicilone A (1), Figure S6: HMBC spectrum of simplicilone A (1), Figure S7: ROESY spectrum of simplicilone A (1), Figure S8: HRESI-Mass spectrum of simplicilone B (2), Figure S9: ${ }^{1} \mathrm{H} \mathrm{NMR}\left(500 \mathrm{MHz}, \mathrm{CDCl}_{3}\right)$ spectrum of simplicilone B (2), Figure S10: ${ }^{13} \mathrm{C}$ NMR $\left(500 \mathrm{MHz}, \mathrm{CDCl}_{3}\right)$ spectrum of simplicilone B (2), Figure S11: HSQC spectrum of simplicilone B (2), Figure S12: HMBC spectrum of simplicilone B (2), Figure S13: COSY spectrum of simplicilone B (2), Figure S14: ROESY spectrum of simplicilone B (2).

Author Contributions: Conceptualization, S.F.K. and F.S.; methodology, B.Y.G.M., F.S. and A.N.; validation, S.F.K.; collection of the plants and isolation of the fungus, E.G.M.A., B.Y.G.M. and S.F.K.; formal analysis, F.S.; investigation, E.G.M.A., B.Y.G.M. and A.N.; writing-original draft preparation, E.G.M.A., B.Y.G.M., S.F.K. and F.S.; writing-review and editing, M.S.; supervision, S.F.K. and F.S.; project administration, S.F.K. and F.S.; funding acquisition, S.F.K. All authors have read and agreed to the published version of the manuscript.

Funding: This research was funded by The World Academy for Science (TWAS), grant number 18-178 RG/CHE/AF/AC_G-FR 3240303654 and the Alexander von Humboldt Foundation in the frame of their research group linkage between the Department of Microbial Drugs Helmholtz Centre for Infection Research, Braunschweig, Germany and the Department of Chemistry, Higher Teacher Training College, University of Yaounde I, Cameroon.

Acknowledgments: Authors are grateful for financial support from The World Academy for Science (TWAS) and the Alexander von Humboldt Foundation. We thank Christel Kakoschke for the measurement of NMR spectra, Vanessa Stiller for excellent technical assistance, Christopher Lambert for strain designation and Marc Stadler for his generous support.

Conflicts of Interest: The authors declare no conflict of interest.

\section{References}

1. Newman, D.J.; Cragg, G.M. Natural products as sources of new drugs over the nearly four decades from 01/1981 to 09/2019. J. Nat. Prod. 2020, 83, 770-803. [CrossRef] [PubMed]

2. Wright, G.D. Opportunities for natural products in 21 st century antibiotic discovery. Nat. Prod. Rep. 2017, 34, 694-701. [CrossRef]

3. Schulz, B.J.E.; Boyle, C.J.C.; Sieber, T.N. Microbial Root Endophytee; Springer: Berlin/Heidelberg, Germany, 2006; Volume 9, pp. 1-13.

4. Tan, R.X.; Zou, W.X. Endophytes: A rich source of functional metabolites (1987 to 2000). Nat. Prod. Rep. 2001, 18, 448-459. [CrossRef] [PubMed] 
5. Lòpez-Fernàndez, S.; Campisano, A.; Schulz, B.J.; Steinert, M.; Stadler, M.; Surup, F. Viriditins from Byssochlamys spectabilis, their stereochemistry and biosynthesis. Tetrahedron Lett. 2020, 61, 151446. [CrossRef]

6. Halecker, S.; Surup, F.; Solheim, H.; Stadler, M. Albiducins A and B, salicylaldehyde antibiotics from the ash tree-associated saprotrophic fungus Hymenoscyphus albidus. J. Antibiot. 2017, 71, 339-341. [CrossRef]

7. Halecker, S.; Wennrich, J.-P.; Rodrigo, S.; Andrée, N.; Rabsch, L.; Baschien, C.; Steinert, M.; Stadler, M.; Surup, F.; Schulz, B. Fungal endophytes for biocontrol of ash dieback: The antagonistic potential of Hypoxylon rubiginosum. Fungal Ecol. 2020, 45, 100918. [CrossRef]

8. Happi, M.G.; Kouam, S.F.; Talontsi, F.M.; Nkenfou, C.; Longo, F.; Ngadjui, B.T.; Spiteller, M. New dimeric naphtopyrones with antimicrobial activity from Aspergillus niger, an Fungal Endophyte isolated from the Cameroonian plant Entandrophragma sp. Zeit Naturforschung 2013, 70, 625-630. [CrossRef]

9. Talontsi, F.M.; Lamshöft, M.; Douanla-Meli, C.; Kouam, S.F.; Spiteller, M. Antiplasmodial and cytotoxic dibenzofurans from Preussia sp. harboured in Enantia chlorantha Oliv. Fitoterapia 2014, 93, 233-238. [CrossRef] [PubMed]

10. Ngadjui, B.T.; Lontsi, D.; Ayafor, J.F.; Sondengam, B. Pachypophyllin and pachypostaudins A and B: Three bisnorlignans from pachypodanthium staudtii. Phytochemistry 1989, 28, 231-234. [CrossRef]

11. Dieter, N. African Ethnobotany: Poisons and Drugs: Chemistry Pharmacology and Toxicology; CRC Press: Boca Raton, FL, USA, 1996; pp. 57-59.

12. Bouquet, A. Féticheurs et Médecines Traditionnelles du Congo-Brazzaville; Mémoire O.R.S.T.O.M.: Paris, France, 1969; Volume 36.

13. Wickens, G.E.; Burkill, H.M. The useful plants of West Tropical Africa. Kew Bull. 1986, 41, 471. [CrossRef]

14. Ngouonpe, A.W.; Mbobda, A.S.W.; Happi, G.M.; Mbiantcha, M.; Tatuedom, O.K.; Ali, M.S.; Lateef, M.; Tchouankeu, J.C.; Kouam, S.F. Natural products from the medicinal plant Duguetia staudtii (Annonaceae). Biochem. Syst. Ecol. 2019, 83, 22-25. [CrossRef]

15. Wei, D.-P.; Wanasinghe, D.N.; Hyde, K.D.; Mortimer, P.E.; Xu, J.; Xiao, Y.-P.; Bhunjun, C.S.; To-Anun, C. The genus Simplicillium. MycoKeys 2019, 60, 69-92. [CrossRef] [PubMed]

16. Ueno, M.; Someno, T.; Sawa, R.; Iinuna, H.; Naganawa, H.; Ishizuka, M.; Takeuchi, T. Delaminomycins, novel nonpeptide extracellular matrix receptor antagonist and a new class of potent immunomodulator. J. Antiot. 1993, 46, 979-984. [CrossRef]

17. Koyama, N.; Nagahiro, T.; Yamaguchi, Y.; Ohshiro, T.; Masuma, R.; Tomoda, H.; Omura, S. Spylidone, a novel inhibitor of lipid droplet accumulation in mouse macrophages produced by Phoma sp. FKI-1840. J. Antibiot. 2005, 58, 338-345. [CrossRef] [PubMed]

18. Hoye, T.R.; Jeffrey, C.S.; Shao, F. Mosher ester analysis for the determination of absolute configuration of stereogenic (chiral) carbinol carbons. Nat. Protoc. 2007, 2, 2451-2458. [CrossRef] [PubMed]

19. Minowa, N.; Kodama, Y.; Harimaya, K.; Mikawa, T. A degradation study of vermisporin and determination of its absolute configuration. Heterocycles 1998, 48, 1639. [CrossRef]

20. Takata, K.; Iwatsuki, M.; Yamamoto, T.; Shirahata, T.; Nonaka, K.; Masuma, R.; Hayakawa, Y.; Hanaki, H.; Kobayashi, Y.; Petersson, G.A.; et al. Aogacillins A and B Produced by Simplicillium sp. FKI-5985: New Circumventors of Arbekacin Resistance in MRSA. Org. Lett. 2013, 15, 4678-4681. [CrossRef] [PubMed]

21. Roy, S.; Dutta, T.; Sarkar, T.S.; Ghosh, S. Novel xylanases from Simplicillium obclavatum MTCC 9604: Comparative analysis of production, purification and characterization of enzyme from submerged and solid state fermentation. SpringerPlus 2013, 2, 382. [CrossRef] [PubMed]

22. Fukuda, T.; Sudoh, Y.; Tsuchiya, Y.; Okuda, T.; Igarashi, Y. Isolation and biosynthesis of preussin B, a pyrrolidine alkaloid from Simplicillium lanosoniveum. J. Nat. Prod. 2014, 77, 813-817. [CrossRef]

23. Dai, Y.; Lin, Y.; Pang, X.; Luo, X.-W.; Salendra, L.; Wang, J.; Zhou, X.; Lu, Y.; Yang, B.; Liu, Y. Peptides from the soft coral-associated fungus Simplicillium sp. SCSIO41209. Phytochemistry 2018, 154, 56-62. [CrossRef]

24. Liang, X.; Zhang, X.; Nong, X.; Wang, J.; Huang, Z.-H.; Qi, S.-H. Eight linear peptides from the deep-sea-derived fungus Simplicillium obclavatum EIODSF 020. Tetrahedron 2016, 72, 3092-3097. [CrossRef]

25. Liang, X.; Nong, X.-H.; Huang, Z.-H.; Qi, S.-H. Antifungal and antiviral cyclic peptides from the deep-sea-derived fungus Simplicillium obclavatum EIODSF 020. J. Agric. Food Chem. 2017, 65, 5114-5121. [CrossRef] [PubMed] 
26. Uchida, R.; Kondo, A.; Yagi, A.; Nonaka, K.; Masuma, R.; Kobayashi, K.; Tomoda, H. Simpotentin, a new potentiator of amphotericin B activity against Candida albicans, produced by Simplicillium minatense FKI-4981. J. Antibiot. 2018, 72, 134-140. [CrossRef] [PubMed]

27. Petrini, O. Endophytic fungi in British Ericaceae: A preliminary study. Trans. Br. Mycol. Soc. 1984, 83, 510-512. [CrossRef]

28. White, T.J.; Bruns, T.; Lee, S.; Taylor, J. 38-Amplification and direct sequencing of fungal ribosomal RNA genes for phylogenetics. In PCR Protocols: A Guide to Methods and Applications; Innis, M.A., Gelfand, D.H., Sninsky, J.J., White, T.J., Eds.; Academic Press: San Diego, CA, USA, 1990; Volume 18, pp. 315-322.

29. Ronquist, F.; Huelsenbeck, J.P. MrBayes 3: Bayesian phylogenetic inference under mixed models. Bioinformatics 2003, 19, 1572-1574. [CrossRef]

30. Nylander, J.A.A. MrModeltest v2. Program Distributed by the Author; Evolutionary Biology Centre, Uppsala University: Uppsala, Sweden, 2004.

31. Surup, F.; Halecker, S.; Nimtz, M.; Rodrigo, S.; Schulz, B.; Steinert, M.; Stadler, M. Hyfraxins A and B, cytotoxic ergostane-type steroid and lanostane triterpenoid glycosides from the invasive ash dieback ascomycete Hymenoscyphus fraxineus. Steroids 2018, 135, 92-97. [CrossRef]

32. Becker, K.; Pfütze, S.; Kuhnert, E.; Cox, R.; Stadler, M.; Surup, F. Hybridorubrins A-D, novel azaphilone heterodimers from stromata of Hypoxylon fragiforme and insights into the biosynthetic machinery for azaphilone diversification. Chem. A Eur. J. 2020. [CrossRef]

Publisher's Note: MDPI stays neutral with regard to jurisdictional claims in published maps and institutional affiliations. 